\title{
POLUIÇÃO E TUTELA PENAL AMBIENTAL
}

\author{
Ivette Senise Ferreira \\ Diretora da Faculdade de Direito da Universidade de São Paulo \\ Professora Titular do Departamento de Direito Penal, Medicina Forense e \\ Criminologia da Faculdade de Direito da Universidade de São Paulo
}

Resumo:

A autora aborda os aspectos jurídicos da poluição, através de nova conceituação como espécie do gênero degradação da qualidade ambiental, resultante de atividades que prejudicam a saúde, a segurança ou, ainda, o bem-estar da população. Disserta, ainda, o parâmetro na tutela penal ambiental desde o Código Penal brasileiro de 1890 até o atual, a poluição descrita em norma jurídica na Lei das Contravenções Penais e na nova lei ambiental, Lei n. 9.605/98.

\begin{abstract}
:
The author approaches the juridical aspects of the pollution, through new conception such as species of the gender degradation of the environmental quality, resultant of activities that harm the health, the safety or, still, the well-being of the population. Dissertate, still, about the parameter in the environmental penal tutelage from the brazilian Penal Code of 1890 to the current, the pollution described in juridical norm in the Law of the Penal Contravention and in the new environmental law, Law n. 9.605/98.
\end{abstract}

Unitermos: nova lei ambiental e suas inovações; comparação com leis anteriores; Direito Comparado.

1. Aspectos jurídicos da poluição.

Poluição, em sentido amplo, significa a modificação das características do ambiente de maneira a torná-lo impróprio ao desenvolvimento das formas de vida nele contidas.

Essa conceituação, porém, abrange inúmeras alterações ambientais que não apresentam interesse prático para a proteção jurídica correlata, ainda que sejam de interesse ecológico, como é por exemplo o caso do incêndio, que não 
constitui propriamente poluição, ou o caso de certas substâncias tóxicas ativas, com valor meramente seletivo, que podem eliminar parte da população biológica em determinado ambiente, mas permitem, ao mesmo tempo, a sobrevivência de outras, ou mesmo o surgimento de novas formas de vida em substituição às anteriores.

Por isso torna-se necessário que a conceituação seja feita com um sentido mais restrito, incluindo elementos indicadores dos prejuízos que se deseja coibir, sejam eles sanitários, econômicos ou estéticos, mas que afetem direta ou indiretamente a vida e o bem-estar humano ou as condições propícias para a sobrevivência de certas espécies animais ou vegetais.

Daí o estabelecimento de conceitos legais, mais ou menos abrangentes, que procuram destacar os aspectos mais relevantes da proteção jurídica que se pretende realizar num âmbito determinado.

Inicialmente a preocupação do legislador brasileiro objetivava a pureza da água, contemplada com a figura penal denominada corrupção ou poluição de água potável, incluída entre os crimes contra a saúde pública no Código Penal de 1940 (art. 271), em que os dois termos eram tomados como sinônimos para designar a imprestabilidade da água para o consumo. Mais tarde a poluição das águas foi legalmente definida no art. $3^{\circ}$ do Decreto n. 50.877, de 29.06.61, como "qualquer alteração das propriedades fisicas, químicas e biológicas das águas, que possa importar em prejuizo à saúde, à segurança e ao bem-estar das populações e ainda comprometer a sua utilização para fins agrícolas, industriais, comerciais, recreativos e principalmente a existência normal da fauna aquática".

Esse conceito foi ampliado posteriormente pelo Decreto n. 73.030, de 30.10.73, que considerou como poluição das águas "qualquer alteração de suas propriedades fisicas, químicas ou biológicas que possa importar em prejuizo à saúde, à segurança e ao bem-estar das populações, causar dano à flora e à fauna ou comprometer o seu uso para fins sociais e econômicos" Adaptava-se assim a noção de poluição à de direito social ou interesse difuso, que começava a prevalecer na legislação, para qualificar o direito ao meio ambiente ecologicamente equilibrado como um valor a merecer per se a tutela penal.

Ao ser instituída a Política Nacional do Meio Ambiente pela Lei n. 6.938, de 31.08.81, que expressamente se destinava a assegurar, entre outros princípios, a proteção dos ecossistemas, o controle e zoneamento das atividades potencial ou efetivamente poluidoras e a recuperação de áreas degradadas ou ameaçadas de degradação, foi a poluição novamente conceituada, sendo qualificada 
como uma espécie do gênero degradação da qualidade ambiental, assim entendidas no seu art. $3^{\circ}$ :

"I meio ambiente, o conjunto de condições, leis, influências e interações de ordem fisica, química $e$ biológica, que permite, abriga e rege a vida em todas as suas formas;

II - degradação da qualidade ambiental, a alteração adversa das características do meio ambiente;

III - poluição, a degradação da qualidade ambiental resultante das atividades que direta ou indiretamente:

a. prejudiquem a saúde, a segurança e o bem-estar da população;

b. criem condições adversas às atividades sociais $e$ econômicas;

c. afetem desfavoravelmente a biota;

d. afetem as condições estéticas ou sanitárias do meio ambiente;

e. lancem matérias ou energia em desacordo com os padrões ambientais estabelecidos."

O mesmo artigo ainda define poluidor, no inciso IV, como "a pessoa fisica ou jurídica, de direito público ou privado, responsável direta ou indiretamente, por atividade causadora de degradação ambiental", e considera recursos ambientais, no inciso V. "a atmosfera, as águas interiores, superficiais e subterrâneas, os estuários, o mar territorial, o solo, o subsolo e os elementos da biosfera"

A redação desse inciso foi depois alterada pela Lei n. 7.804, de 18.07.89, que acrescentou, depois da palavra biosfera, também a fauna e a flora. Outra alteração foi a substituição do art. 15 da Lei n. 6.938/81 por uma incriminação do poluidor no chamado delito de "poluição perigosa" que será adiante analisado.

Observa Paulo Affonso Leme Machado que a legislação estadual e a municipal podem ampliar o conceito de poluição, mas serão de nenhum efeito se restringirem a proteção legal dada pela conceituação federal ("Direito Ambiental Brasileiro" $2^{\text {a }}$ ed., R.T., 1989, p. 250). Acrescenta o autor que a legislação estadual não varia muito da conceituação da legislação federal, mas aponta algumas 
diferenças: no Estado do Rio de Janeiro acrescenta-se nessa tutela "o equilibrio ecológico" "as propriedades públicas e privadas" e a "harmonia com os arredores naturais"; no Rio Grande do Sul cita-se a proteção de diversas atividades, inclusive recreativas; em Minas Gerais é também ato poluidor o fato de causar dano relevante ao acervo histórico, cultural e paisagístico.

É interessante destacar que a simples desobediência a padrões ambientais estabelecidos pelos órgãos competentes pode constituir ato poluidor $\mathrm{e}$ como tal deverá ser incluído nos tipos penais referentes à poluição nas várias formas em que esta pode apresentar-se. De acordo com a complexidade do bem jurídico que será protegido com a incriminação da poluição, pode ela se apresentar em várias modalidades, que deverão ser diferentemente apreciadas pelo legislador: poluição das águas, poluição atmosférica, do solo, por pesticidas, por resíduos sólidos ou lançamento de dejetos, poluição sonora, poluição visual, etc., as quais passaremos a analisar no confronto necessário com a Lei n. 9.605/98.

2. A poluição das águas.

2.1. Na legislação anterior.

2.1.1. No Código Penal de 1890:

A poluição das águas constituiu também no Brasil a primeira preocupação do legislador em matéria ambiental por serem elas necessárias à manutenção da vida na face da Terra, sobressaindo como um bem de proteção necessária para a saúde individual e coletiva e de consumo imprescindível.

No Código Penal brasileiro de 1890 (Decreto n. 847, de 11.10.1890) o seu envenenamento já era tipificado no art. 161 como "envenenar fontes públicas ou particulares, tanques ou viveiros de peixe e viveres destinados a consumo", fato punido com prisão celular por dois a seis anos e, se do envenenamento resultasse a morte de alguém, prisão celular por seis a quinze anos. Pena menor, de prisão celular por um a três anos, era prevista no art. 162 para o fato de "corromper, ou conspurcar, a água potável de uso comum ou particular, tornando-a impossivel de beber ou nociva à saúde". 
2.1.2. No Código Penal de 1940:

Mantendo a mesma orientação, o Código Penal de 1940 inscreveu as duas modalidades entre os "crimes contra a saúde pública" com ligeira modificação da terminologia empregada, sendo elas apresentadas como envenenamento de água potável ou de substância alimenticia ou medicinal (art. 270) e corrupção ou poluição de água potável (art. 271), com a seguinte redação:

Art. 270: Envenenar água potável, de uso comum ou particular, ou substância alimenticia ou medicinal destinada a consumo: Pena - reclusão de 10 (dez) a 15 (quinze) anos.

$\S l^{\circ}$ Está sujeito à mesma pena quem entrega a consumo ou tem em depósito, para o fim de ser distribuida, a água ou a substância envenenada.

$\S 2^{\circ}$ Se o crime é culposo: Pena-detenção, de 6 (seis) meses a 2 (dois) anos.

Art. 271. Corromper ou poluir água potóvel, de uso comum ou particular, tornando-a imprópria para consumo ou nociva à saúde: Pena-reclusão, de 2 (dois) a 5 (cinco) anos.

Parágrafo único. Se o crime é culposo: Pena detenção, de 2 (dois) meses a 5 (cinco) anos.

Deve-se notar contudo que a pena estipulada no art. 270 foi determinada pela Lei n. 8.072, de 25 de julho de 1990, que dispõe sobre os crimes hediondos, que no seu art. $6^{\circ}$ majorou as sanções de alguns crimes previstos no Código Penal. Antes disso a pena cominada era a de reclusão de 5 (cinco) a 15 (quinze anos).

A restrição que faz o tipo penal quanto à natureza da água, que deve ser potável, não impede que a tutela se estenda a qualquer dispersão aquosa, perene ou efêmera, onde quer que esteja contida, abrangendo pois tanto os rios quanto os riachos, açudes, as lagoas, represas, fontes e outros mananciais, tanto de superfície quanto subterrâneos.

A preocupação com a água potável, que restringiu o preceito incriminatório, expressa na verdade o posicionamento de uma legislação pré- 
ambiental que tencionava proteger apenas o indivíduo em seus interesses fundamentais, entre os quais a sua vida e a sua saúde, sem atentar para os outros entes e a natureza como um todo, desconsiderando, no caso das águas, a poluição nociva aos vegetais e aos animais, esquecendo-se que deles também nos servimos e por isso a sua destruição igualmente nos afeta.

Tem sido destacada por vários autores a contribuição jurisprudencial para o alargamento do conceito de potabilidade da água, referido nos dois dispositivos citados, de molde a abranger qualquer outra água que, embora de maneira indireta, possa servir à alimentação humana, seguindo a orientação vigente em outros países, em que a incriminação é constituída muitas vezes pelo simples lançamento à água de substâncias ou resíduos que possam alterar a sua qualidade.

Esther de Figueiredo Ferraz, comentando essa jurisprudência, aponta para os riscos de proceder-se assim a uma incriminação analógica, diversa da que seria a mera interpretação extensiva, a qual é até mesmo recomendável no âmbito penal, enquanto que a primeira atingiria o princípio da legalidade dos delitos e das penas e deve ser evitada mesmo que tenha por escopo a correção da norma incorreta ("Defesa penal do meio ambiente" in Anais do CONJUR, v. XXI, FIESP, SP, 1988, p. 15). Por isso preconiza a mestra que o reforço da tutela ao meio ambiente se faça não pela via da jurisprudência mas pela via legislativa. É o que se tentou fazer em 1969, no Código Penal promulgado, mas que não chegou a vingar, onde se previa, ao lado dos delitos de envenenamento e de corrupção ou poluição de água potável (arts. 299 e 301), um outro de poluição de fluidos, no art. 300, punido com reclusão até três anos e multa, que era porém muito mal formulado, nos seguintes termos: "Poluir lago, curso de água, o mar ou, nos lugares habitados, as praias e a atmosfera, infringindo prescrições de lei federal"

A questão tem encontrado soluções bastante diversificadas no Direito Comparado.

No Canadá, a Lei de Proteção das Águas, de 1970, pune o lançamento de resíduos que contribuam para o processo de degradação ou alterem a qualidade das águas, em detrimento de sua utilização pelo homem ou por animal, peixe ou planta utilizados pelo homem. Na Bélgica, incrimina-se o lançamento à água de matérias nocivas e na Suiça a lei federal sobre a proteção das águas, de 1971, pune tanto aquele que ilicitamente lança ou introduz nas águas matérias sólidas, líquidas ou gasosas de forma a polui-las, quanto aquele que deposita fora das águas ou deixa infiltrar no subsolo matéria que possa poluir ou criar o risco de poluição da água. 
Em algumas legislações preferiu-se porém vincular a infração penal a certas condições de autorização ou ao descumprimento das normas administrativas sobre lançamentos de dejetos. É o caso da Holanda, onde são punidas as infrações às condições de autorização ou às normas de lançamentos nos cursos d'água, de matérias perigosas. No mesmo sentido dispõem a lei italiana, de 1976, e a Lei de Proteção ao Meio Ambiente da Suécia, de 1969.

A Inglaterra, pioneira no combate à poluição das águas com o seu River's pollution prevention Act, de 1876, reforçou as suas prescrições em 1974, segundo preleciona Paulo Affonso Leme Machado ("Direito Ambiental Brasileiro" ob. cit., p. 251), punindo não-somente o lançamento às águas de quaisquer matérias venenosas, nocivas ou poluidoras, bem como o lançamento de matérias que impeçam o normal fluxo da água, aumentando ou agravando poluição já existente.

Embora a água seja um dos bens mais preciosos da natureza, essencial à vida na Terra sob todas as suas formas, o delito previsto no art. 270 do Código Penal brasileiro visa especialmente proteger a saúde pública e a vida das pessoas, que poderiam ser afetadas pelo envenenamento das águas ou das substâncias alimentícias ou medicinais.

Assim, não se acha revogado pela Nova Lei Ambiental, que sobre o assunto tem um dispositivo genérico, sobre poluição de qualquer natureza, e outros específicos que tratam da poluição hídrica.

O critério adotado no delito do art. 270 do Código Penal é o do perigo que paira sobre esses bens jurídicos na eventualidade de seu consumo, motivo pelo qual basta o dano potencial, não sendo exigível a ocorrência do mesmo, o que o caracteriza como um crime de perigo abstrato. Na ocorrência efetiva de um dano, sob a forma de lesão corporal de natureza grave ou da morte de alguém, teremos as formas qualificadas pelo resultado previstas no art. 285 combinado com o disposto no art. 258, aumentando-se as penas da metade ou aplicando-as em dobro, conforme o caso.

A conduta, expressa pelo verbo envenenar, ou seja, lançar veneno de forma a contaminar a água tornando-a tóxica, orgânica ou inorgânica, e prejudicial à saúde de um número indeterminado de pessoas, abrange todos os meios idôneos que direta ou indiretamente produzam esse efeito, sendo necessário que se apure em perícia técnica a propriedade venenosa da substância lançada, para a verificação da alteração ou destruição das propriedades originais da matéria. 
Na modalidade do $\S 1^{\circ}$ do art. 270 a conduta consistirá em entregar a consumo ou ter em depósito para distribuir a água ou substância envenenada, que acarretará a mesma pena prevista no caput.

No tipo doloso, sustenta Nelson Hungria não estar compreendido o animus occidendi mas apenas a consciência de que o agente está criando uma situação de perigo comum, pelo conhecimento que deve ter da natureza do meio empregado e da destinação do objeto. Alega que somente um indivíduo psiquicamente anormal seria capaz de envenenar um reservatório de água potável ou depósito de víveres visando a morte de pessoas indeterminadas ou que ele de antemão não sabe quais possam ser ("Comentários ao Código Penal", v. IX, Forense, Rio de Janeiro, p. 105). Essa é também a opinião de Heleno Fragoso ("Lições de Direito Penal", v. II, Forense, Rio de Janeiro, 1984, p. 209). Paulo José da Costa Jr. permite-se discordar, assentado em Manzini, afirmando consistir o dolo, nesse dispositivo, na vontade consciente e livre bem como na intenção de envenenar a água ou as substâncias especificadas, sabendo qual é a sua destinação. E por sabêlas destinadas a um número indeterminado de pessoas estará aceitando, ainda que eventualmente, a morte delas ("Comentários ao Código Penal" v. 3, Saraiva, São Paulo, 1989, p. 265).

O tipo culposo, que pressupõe a negligência, a imprudência ou imperícia do agente, e a previsibilidade do evento não-previsto, abrange tanto o envenenamento quanto as formas equiparadas da conduta mencionada no $\S 1^{\circ}$ do art. 270. Nessas modalidades, exemplifica Paulo José da Costa Jr., pode ocorrer que o agente mantenha em depósito, por negligência, substância que não sabe envenenada, mas que teria condições de saber; ou que o agente entregue a consumo alimento que poderia presumir deteriorado, embora não tenha consciência plena da condição em que a substância se apresenta.

Quanto ao delito de corrupção ou poluição de água potável previsto no art. 271, também aqui não se trata de proteger a água como um bem natural, mas sim a saúde pública, valendo então as mesmas observações já feitas para o artigo precedente. Sendo também crime de perigo abstrato ou presumido é todavia de menor gravidade do que a figura típica do art. 270 , sendo que o verbo corromper transmite a idéia de estragar, e poluir a de sujar a água, tornando-a imprópria para o consumo ou nociva à saúde.

Nelson Hungria define com muita propriedade: "Corromper a água é alterar-lhe a essência ou composição, tornando-a nociva à saúde, ou intolerável 
pelo mau sabor. Poluir a água é conspurcá-la, deitar-lhe alguma sujidade, de modo a torná-la imprópria de ser bebida pelo homem." (ob. cit.)

Igualmente neste caso, segundo a melhor doutrina, deve-se entender como água potável não apenas a que é bioquimicamente pura, mas a que é boa para beber e cozinhar, servindo tanto às pessoas quanto aos animais.

Esse dispositivo porém levou a uma controvérsia doutrinária e jurisprudencial sobre a possibilidade de considerar-se a sua ocorrência na hipótese de a água já estar poluída. Esther de Figueiredo Ferraz afirma que em hipótese nenhuma a água já poluída poderá ser tutelada pelo art. 271, uma vez que não se trata de água potável, citando em seu favor inúmeros acórdãos concedendo a absolvição do acusado por ausência de potabilidade da água ("O crime de poluição de água potável" in Estudos em homenagem ao Professor Silvio Rodrigues, Saraiva, São Paulo, 1989, pp. 114 e ss.).

Em sentido oposto manifestam-se aqueles que entendem, segundo uma interpretação extensiva, que devem ser criminalizadas as condutas dos que poluem a água "potencialmente potável", a qual poderia ser recuperada mediante tratamento adequado que a transformaria em potável. Nesse sentido, todas as águas são potencialmente potáveis. Esse argumento porém é rejeitado pela autora citada, primeiramente porque a expressão "água potencialmente potável" não tem sentido do ponto de vista científico, uma vez que pode ser aplicável a qualquer água mesmo a extremamente poluída, e em segundo lugar porque aquilo que se aponta como mero recurso de hermenêutica (a interpretação extensiva) na verdade seria um recurso à analogia, com infringência do princípio da reserva legal, o qual norteia todo o sistema jurídico-penal.

A discussão perdeu o sentido com a edição da Lei n. 6.938, em 1981, que tipificou o crime de poluição em geral, o qual constitui na exposição a perigo da incolumidade humana, animal ou vegetal, ou o agravamento de perigo já existente, expressão que abrange a situação que é objeto da controvérsia e que agora é enfocada nos termos de uma política global, instituída nesse mesmo diploma legal e que tem por objetivo a preservação, a melhoria e a recuperação da qualidade ambiental propícia à vida.

De qualquer forma, sendo um crime contra a saúde pública, a ele aplica-se o disposto no art. 285 do Código Penal, que remete ao art. 258, salvo para o delito de epidemia, a ocorrência de um resultado danoso à vida ou à saúde nesses crimes, quando a pena será majorada, tanto nos tipos dolosos quanto nos culposos. 
2.1.3. Na Lei n. 6.938 , de 31 de agosto de 1981:

No art. 15 da Lei n. 6.938/81 figura um tipo penal intitulado por alguns de poluição em geral ou poluição genérica, por outros de poluição perigosa, que poderia também ser aplicado à poluição das águas nos casos em que especifica, cuja redação e inclusão nesse diploma legal foi ditada pela Lei n. 7.804, de 18 de julho de 1989, nos seguintes termos:

Art. 15 O poluidor que expuser a perigo a incolumidade humana, animal ou vegetal, ou estiver tornando mais grave situação de perigo existente, fica sujeito à pena de reclusão de I (um) a 3 (três) anos e multa de 100 (cem) a 1.000 (mil) MVR.

$\S 1^{\circ}$ A pena é aumentada até o dobro se:

I- resultar:

a. dano irreversível à fauna, à flora e ao meio ambiente;

b. lesão corporal grave;

II a poluição é decorrente de atividade industrial ou de transporte;

III o crime é praticado durante a noite, em domingo ou em feriado.

$\S 2^{\circ}$ Incorre no mesmo crime a autoridade competente que deixar de promover as medidas tendentes a impedir a prática das condutas acima descritas."

Esse delito destinava-se a preencher as lacunas existentes na legislação então em vigor no que se refere às várias formas de poluição, pretendendo-se que fosse mais eficiente para a defesa do meio ambiente do que as poucas normas que podiam ser aplicadas a essas situações, uma vez que tanto na sua forma comissiva quanto na omissiva dispensava a ocorrência de dano efetivo, bastando que se verificasse a situação de perigo mencionada, caracterizada pelo risco à incolumidade humana, animal ou vegetal, dolosamente provocado, o que era bastante difícil provar... 
Evidentemente era também admissível no caso da poluição das águas, sem as restrições sobre a sua qualidade, como as que existem no Código Penal, mas a sua redação extremamente defeituosa, assim como a inexistência da forma culposa (que é a que mais comumente se verifica) tornavam difícil senão impossível a sua aplicação. Embora escassa a sua jurisprudência, Gilberto Passos de Freitas consegue nos apresentar um caso em que foi julgada procedente ação penal movida contra prefeito municipal que admitiu que se jogasse lixo em rio caudaloso, decidindo o TJRS pela sua condenação (4a Câm. Crim., Ap. 692.052.111, in "Crimes contra a natureza". $4^{a}$ ed., RT, 1995, p.124).

Por outro lado, o sujeito ativo do delito, designado como poluidor, tinha a sua conceituação referida na mesma lei, no seu art. $3^{\circ}$, que considerava tal " $a$ pessoa fisica ou jurídica, de direito público ou privado, responsável, direta ou indiretamente, por atividade causadora de degradação ambiental" mas que por força do sistema penal então vigente só podia ser a pessoa física, já que ainda não fôra acolhida a responsabilidade penal da pessoa jurídica, hoje existente na Lei $n$. $9.605 / 98$.

A poluição genérica foi retomada nessa nova lei ambiental em outros termos e com outra sanção, motivo pelo qual encontra-se revogado hoje o art. 15 da Lei n. 6.938/81, mas não as conceituações do seu art. $3^{\circ}$, referentes a meio ambiente, poluição, degradação ambiental, poluidor, etc., que continuam a nos fornecer os parâmetros para a apreciação dos bens ambientais tutelados na ordem jurídica.

\subsection{Na Nova Lei Ambiental.(Lei n. 9.605/98):}

A Lei n. 9.605/ 98, no seu art. 54, dispôs sobre poluição de qualquer natureza, não fazendo distinção quanto às suas várias modalidades a não ser para qualificar o crime, no $\S 2^{\circ}$ : impondo pena mais grave para as atuações mais danosas ou de maior risco para a saúde, ou que atinjam mais significativamente a flora ou a fauna.

Assim, na sua Seção IIl Da Poluição e outros Crimes Ambientais, dispõe:

"Art. 54. Causar poluição de qualquer natureza em niveis tais que resultem ou possam resultar em danos à saúde humana, ou que provoquem a mortandade de 
animais ou a destruição significativa da flora: Penareclusão, de um a quatro anos, e multa."

Nos seus parágrafos são previstas a forma culposa, punida com detenção de seis meses a um ano e multa, as formas qualificadas, punidas com reclusão de um a cinco anos, e uma forma omissiva de conduta que lhe é equiparada, punindo com a mesma pena do crime qualificado "quem deixar de adotar, quando assim o exigir a autoridade competente, medidas de precaução em caso de risco de dano ambiental grave ou irreversível."

Uma referência expressa à poluição hídrica é feita no inciso III do § $2^{\circ}$, indicando como causa da majoração penal a hipótese de ser necessária a interrupção do abastecimento público de água numa comunidade. E o inciso IV refere-se à circunstância da poluição "dificultar ou impedir o uso público das praias" tarnbém considerada qualificadora, situação comumente provocada pelo lançamento de esgoto e outros dejetos em canais ou cursos d'água que desembocam no mar, ou diretamente nas praias e águas litorâneas. A hipótese do inciso $\mathrm{V}$, referente ao "lançamento de resíduos sólidos, líquidos ou gasosos, ou detritos, óleos ou substâncias oleosas, em desacordo com as exigências estabelecidas em leis e regulamentos" igualmente pode ocorrer em águas de todas as espécies, tornando-a imprópria para a utilização pelo homem, como também para os animais e para as plantas.

Ficou assim a poluição das águas mais adequadamente abrangida em todos os seus aspectos na nova definição legal que lhe deu a Lei n. 9.605/98, inclusive com a introdução da forma culposa desse delito, que se fazia necessária pela grande incidência das atitudes de negligência e descaso dos agentes poluidores, os quais, segundo a regra do art. $7^{\circ}$, serão todavia beneficiados com a substituição da pena privativa de liberdade por uma restritiva de direitos, que poderá constituir-se numa prestação de serviços à comunidade, ou numa interdição temporária de direitos, suspensão parcial ou total de atividades, prestação pecuniária ou recolhimento domiciliar.

Contudo se o crime for doloso haverá especial aumento da pena a ser aplicada, de acordo com as regras do art. 58, se do fato não resultar crime mais grave, a saber:

a. de um sexto a um terço, se resulta dano irreversivel à flora ou ao meio ambiente em geral; 
b. de um terço até a metade, se resulta lesão corporal de natureza grave em outrem;

c. até o dobro, se resultar a morte de outrem.

A multa prevista como sanção cumulativa será calculada de acordo com os critérios do Código Penal, podendo ser aumentada, se revelar-se ineficaz mesmo que aplicada no valor máximo, até três vezes, levando em conta o valor da vantagem econômica auferida. Se o crime for praticado por pessoa jurídica, a lei autoriza que a sua aplicação seja isolada, cumulativa ou alternativa com as penas restritivas de direitos ou de prestação de serviços à comunidade adequadas à sua natureza.

\section{A poluição atmosférica.}

3.1. Na legislação anterior:

3.1.1. No Código Penal de 1940:

Figuras típicas referentes à poluição atmosférica não encontram precedentes na legislação anterior ao Código Penal de 1940, mas tanto no Projeto Sá Pereira quanto no Projeto Alcântara Machado, apresentados respectivamente em 1935 e 1938 para a reforma da legislação penal, incluíam o delito de uso de gás tóxico entre os crimes contra a incolumidade pública, que foi finalmente adotado pela legislação editada em 1940 e assinalada a sua novidade na respectiva Exposição de Motivos.

Nelson Hungria aponta o Código Penal suíço como fonte do dispositivo e de fato parece ter sido este o primeiro a mencionar o gás tóxico como substância perigosa à vida, saúde ou propriedade de outrem ("Comentários ao Código Penal", v. IX, Rio de Janeiro, Forense, 1958, p. 40). Com a rubrica uso de gás tóxico ou asfixiante, esse delito é a única hipótese existente no Código Penal referente à poluição atmosférica, mas que não se destina à defesa ambiental e sim à proteção da incolumidade pública nos aspectos que a conduta descrita apresenta de perigo comum à vida, saúde ou patrimônio de outrem, estando assim descrita:

"Art. 252. Expor a perigo a vida, a integridade fisica ou o patrimônio de outrem, usando de gás tóxico ou asfixiante: Pena - reclusão, de l (um) a quatro (quatro) anos e multa. 
Parágrafo único. Se o crime é culposo: Pena detenção de 3 (três) meses a l (um) ano."

Como se percebe, essa entidade criminal é absolutamente inadequada para enfrentar o problema do uso ou das descargas de substâncias poluentes na atmosfera em nosso planeta, que inegavelmente além de representar um sério perigo à vida animal e vegetal, incomodar as pessoas e destruir ou alterar a constituição das coisas, chegam efetivamente a causar danos sérios quando em altos níveis, sendo responsabilizada essa espécie de poluição por inúmeras moléstias, principalmente das vias respiratórias, que afligem os habitantes das grandes cidades ou dos locais vizinhos a instalações industriais ou vias de trânsito intenso.

Além disso a expressão "gás tóxico ou asfixiante" não esgota toda a variedade de gases nocivos a todos os seres da natureza que são objeto da proteção ao meio ambiente, embora nessas categorias estejam os gases venenosos e os asfixiantes, que são os mais perigosos para a vida e a saúde da espécie humana.

Além do uso dos gases mencionados, o Código Penal incrimina a seguir, no art. 253, o seu fabrico, fornecimento, aquisição, posse ou transporte aí incluindo os explosivos, cominando nesses casos a pena de detenção de seis meses a dois anos, além da multa. A objetividade jurídica é a mesma do delito anterior e o perigo comum é presumido juris et de jure e por isso não necessita ser comprovado, tratando-se de atos preparatórios para o uso do material referido, subordinados porem à existência de um elemento normativo, que foi incluído no tipo, constituído pela ausência de licença da autoridade.

\subsubsection{Na Lei das Contravenções Penais (Decreto-lei n. 3.688, de 3.10.41):}

Embora seja essa a modalidade mais comum de poluição, extremamente danosa sobretudo nos grandes centros urbanos em razão das atividades industriais e do número excessivo de veículos, cujas emanações degradam a qualidade do ar e causam o aquecimento do planeta pelo chamado "efeito estufa" o lançamento de elementos nocivos na atmosfera foi previsto somente como contravenção penal pelo Decreto-lei n. 3.688, de 03 de outubro de 1941 , e punido levemente com a multa contravencional.

O tipo está assim descrito no art. 38: "Provocar, abusivamente, emissão de fumaça, vapor ou gás, que possa ofender ou molestar alguém", pelo que 
deve ser constatado o abuso na emissão dessas substâncias, com a consulta e o enquadramento da conduta nas normas ou tabelas que existem a esse respeito, tratando-se pois de norma penal em branco, que implica inclusive na medição dos poluentes para a verificação dos seus níveis. Pode-se contudo entender como abusiva a emissão desnecessária, mesmo não excedendo os limites permitidos.

De qualquer forma, o abuso deve poder ser constatado na emissão, pois muitas vezes tais ocorrências são justificadas na atividade industrial pelo exercício normal de um direito inerente às operações nela desenvolvidas. Assim afirma Manoel Carlos da Costa Leite: "Desde que a emissão de gás, fumaça ou vapor cause incômodo, molestando ou ofendendo, e tal emissão não advenha do exercício regular do direito, ocorre a contravenção" ("Manual das Contravenções Penais", São Paulo, Saraiva, 1962, p. 151). Assim também entendeu a jurisprudência dos nossos tribunais, de que é exemplo o acórdão publicado na RT 434/400: "Não tendo havido abuso, mas sim o exercício normal de um direito, sendo o fumi immitendi e o odoris immitendi das indústrias um ônus ou incômodo daqueles que residem na zona industrial das cidades, não se configura a contravenção do art. 38 da respectiva lei."

Tal posicionamento dos tribunais e, por outro lado, o aumento da poluição ambiental produzida pelas atividades industriais nos grandes centros, causando incômodos à população e malefícios aos bens da natureza em geral, tornavam necessário que o abuso fosse constatado por provas técnicas que pudessem demonstrá-lo, bem como exigiam o estabelecimento dos índices a serem respeitados. Devia assim o Poder Público estabelecer previamente quais as substâncias que podem ser lançadas no ar e em que quantidades, para evitar-se que ofendam ou incomodem alguém, uma vez que no âmbito contravencional não estão em cogitação maiores danos.

Ora, é inegável que a inalação das substâncias referidas na contravenção pode produzir efeitos que vão muito além do simples incômodo ou molestamento mencionados, causando danos muitas vezes irreversíveis à saúde do homem e destruindo a fauna e a flora do local, além de outros estragos na natureza. A fumaça, em que se misturam partículas sólidas com vapores e gotículas de líquido, constitui a emissão típica de certas indústrias, como a siderúrgica, a de cimento e a de certos produtos químicos, como também dos veículos automotores, sendo extremamente danosa e responsável por certas moléstias. Quanto ao vapor e ao gás, podem conter em estado gasoso certos elementos tóxicos, como é o caso do 
monóxido de carbono, produzido pelos veículos no trânsito, que é altamente nocivo e prejudicial à saúde.

Era assim mais apropriado o enquadramento desses poluidores em norma mais severa, como é o caso do art. 252 do Código Penal que contempla o uso de gás tóxico ou asfixiante, que é um crime de perigo comum, embora limitado à proteção daqueles que estiverem expostos às emanações dessas substâncias, as quais porém não deixam de ser também poluentes.

Sendo um crime de perigo concreto, nesse caso teria que ser analisada a qualidade do gás e as suas propriedades perigosas, mas não necessariamente mortais, as quais atuariam por envenenamento, causando a intoxicação do organismo, ou por sufocação, causando a asfixia do indivíduo.

Sua aplicação ainda assim seria extremamente limitada para enfrentar certas modalidades de poluição atmosférica, as quais estariam também compreendidas inegavelmente na poluição perigosa descrita no art. 15 da Lei n. 6.938/81, com a redação determinada pela Lei n. 7.804/89, já mencionado ao tratarmos da poluição hídrica. Essa figura penal, na sua fórmula genérica de exposição a perigo, que é subsidiária para todos os delitos de poluição, tutela a incolumidade humana, animal ou vegetal, com ampla possibilidade de proteção legal da vida de todos os seres e bens da natureza. Entre as circunstâncias que tornam crime qualificado a do inciso II ("se a poluição é decorrente de atividade industrial ou de transporte") relaciona-se enormemente com a degradação atmosférica que se pretende evitar para assegurar o meio ambiente ecologicamente equilibrado e a sadia qualidade de vida a que a norma constitucional faz referência.

De qualquer modo, o referido artigo encontra-se revogado pela nova lei ambiental, que disciplinou de outra forma a poluição em geral ou poluição perigosa, assim como se pode considerar revogada a contravenção, absorvida nessa conduta.

\subsection{Na Nova Lei Ambiental.}

A Lei n. 9.605/98 ao incriminar no seu art. 54 o ato de "causar poluição de qualquer natureza em niveis tais que resultem ou possam resultar em danos à saúde humana, ou que provoquem a mortandade de animais ou a destruição significativa da flora" evidentemente teve por objetivo encontrar uma fórmula genérica para enquadrar todas as modalidades de degradação ambiental e, 
entre elas, as que contaminam a atmosfera com elementos nocivos à saúde e à vida em geral na natureza, que na sua forma mais grave pode levar à causa de aumento de pena prevista no inciso II desse mesmo artigo, o qual eleva a pena para reclusão de um a cinco anos se o crime "causar poluição atmosférica que provoque a retirada ainda que momentânea, dos habitantes das áreas afetadas, ou que cause danos diretos à saúde da população"

Nessa modalidade de poluição, que só é incriminada quando seus níveis se tornam intoleráveis ou perigosos, ou então danosos à saúde, há necessidade de proceder-se a verificações técnicas que evidentemente ficam fora da lei penal incriminadora, e devem ser buscadas em outras normas específicas baixadas pelo Poder Público, de preferência locais, que solucionam determinados problemas em determinadas áreas. São encontradas na legislação administrativa e abrangem, por exemplo, as prescrições impostas aos estabelecimentos industriais para funcionamento, ou então as que incidem sobre combustíveis e aparelhos de combustão, que são os principais responsáveis pela poluição do ar. Atenção especial vem sendo dada às prescrições técnicas concernentes à construção de veículos automotores e à sua utilização principalmente quanto ao controle de monóxido de carbono no seu gás de escape, altamente nocivo pela sua toxidade.

Paulo Affonso Leme Machado menciona os instrumentos administrativos mais eficientes para a prevenção da poluição atmosférica que incluem: os padrões de qualidade do ar, as normas de emissão, o licenciamento, a informação periódica da fonte emissora, a fiscalização pela autoridade pública, pelos próprios empregados da fonte poluidora, pelas associações ambientalistas, etc. ("Direito Ambiental Brasileiro", $2^{a}$ ed., RT, p. 292).

Os padrões de qualidade do ar, que devem servir de referencial para avaliar a gravidade da situação em determinado momento, estão fixados na Portaria n. 0231/76, do ministro do Interior, e nela estão estabelecidas "as concentrações de poluentes atmosféricos que, ultrapassadas, poderão afetar a saúde, segurança e bem-estar da população, bem como ocasionar danos à flora e à fauna e ao meio ambiente em geral"

São também relevantes nessa matéria, fornecendo elementos para o preenchimento da conduta na norma penal em branco, a Lei n. 6.803/80, que dispõe sobre as diretrizes básicas para zoneamento industrial nas áreas críticas de poluição; a Portaria n. 100, de 14.07.80, do ministro do Interior, que dispõe sobre emissão de fumaça dos veículos a óleo diesel; o Decreto-lei n. 1.413/75 e o Decreto n. 
$76.389 / 75$, que dispõem sobre o controle da poluição do meio ambiente provocada por atividades industriais. Essas normas estão em constante aperfeiçoamento, muitas vezes com medidas de validade local, como é o caso do rodízio de veículos por dias da semana, em vigor na cidade de São Paulo, a proibição do tráfego em certas áreas urbanas, etc. As normas administrativas, todavia, têm escasso poder intimidativo e as multas aplicadas não têm sido suficientes para impedir as transgressões. Mais recentemente tivemos a edição de um novo Código de Trânsito, a Lei n. 9.503/97, que com sanções mais severas na área penal e administrativa pretende disciplinar condutas inadequadas na condução de veículos com o fim de evitar não-somente os danos e perigos a que todos estamos sujeitos no trânsito, mas também melhorar a manutenção e diminuir o uso abusivo dos veículos como instrumentos necessários às exigências da vida moderna, porém altamente poluidores do meio ambiente, sobretudo da atmosfera.

A prevenção da poluição na verdade tem hoje enorme importância em todo o mundo, particularmente nos países europeus entre os quais se destacam a França, a Alemanha e a Itália. Na França tem inspirado numerosos textos jurídicos, como o Código Urbanístico, o Código de Trânsito e os regulamentos sanitários departamentais, além de uma lei especificamente dirigida ao controle da poluição atmosférica, a Lei n. 61.842, de 13.05.74, concernente ao controle das emissões poluentes na atmosfera e a certas utilizações da energia térmica.

Essa lei estabeleceu uma série de controles para as instalações de determinadas indústrias ou atividades, principalmente as de incineração, combustão ou aquecimento, e para a qualidade dos combustíveis e a nocividade de suas emissões poluentes na atmosfera. Outros dispositivos foram consagrados à emissão de fumaça e partículas, sobretudo através de chaminés de liberação. Foram ainda estabelecidas zonas de proteção especial a fim de limitar a poluição da atmosfera, no interior das quais são aplicáveis disposições particulares concernentes ao uso de combustíveis, funcionamento das instalações de combustão e limites máximos de poluentes nas emissões, ficando elas subordinadas a períodos de alerta no caso de sensível e perigoso aumento da poluição atmosférica.

Para assegurar a eficácia de todos esses controles a Lei n. 61.842/61, modificada pela Lei de 30 de dezembro de 1977, incriminou a inobservância dessas normas, punindo com a pena de prisão por dez dias a três meses e multa de 400 a 30 mil francos "aquele que puser obstáculo à realização dos controles visados pelos artigos segundo e terceiro" E no seu art. $6^{\circ}$ a mesma Lei, também modificada em 
1977, pune com prisão de dois a seis meses, e multa de 10 mil a 120 mil francos, aquele que tiver feito funcionar uma instalação com infração a uma medida de interdição aplicável até o encerramento dos trabalhos prescritos para remediar a poluição, de acordo com o art. $5^{\circ}$

Com relação à poluição causada no trânsito pelos veículos automóveis, vários textos regulamentam de forma técnica os principais tópicos contidos no princípio enunciado no artigo R.69 do Código de Trânsito francês, segundo o qual "os veículos automóveis não devem emitir fumaça, gás tóxico, corrosivo ou odorante, em condições suscetiveis de incomodar a população, ou de comprometer a saúde e a segurança públicas" Com o objetivo de assegurar esse princípio, várias disposições sobre a utilização de veículos proíbem a emissão de fumaças coloridas ou opacas, a manutenção em funcionamento do motor do veículo durante o seu estacionamento, e a emissão de gás contendo mais de 4,5\% de monóxido de carbono. Outros controles são estabelecidos para a construção dos veículos, o seu trânsito na via pública, o teor de enxofre e de chumbo nos carburantes, etc.

Uma infração contravencional de desobediencia aos textos em vigor e de desrespeito aos controles é prevista no Código Nacional de Trânsito francês, implicando em sanções que podem ser simplesmente de multa, mas tambem de prisão em caso de reincidência. (M. Despax et W. Coulet "Loi et pratique concernant le contrôle de la pollution en France", Librairies Techniques; Paris, 1983, p. 42).

Nos Estados Unidos, um Clean Air Act, editado em 1970 e emendado em 1974, impõe multas aos poluidores da atmosfera, que podem ser cumulativas com a pena de prisão até um ano. Na reincidência, além de majorar-se o valor da multa, que pode alcançar os 50 mil dólares por dia de violação, a prisão pode alcançar até dois anos, sendo aplicável alternativa ou cumulativamente com a pena de multa.

Por fim, na moderna Europa, o Direito Comunitário, ainda em consolidação, tem contribuído enormemente com as suas diretivas para reforçar a política e a legislação referentes à poluição atmosférica nos países da União Européia. O esforço é dirigido principalmente para solucionar os problemas da poluição causada pelos veículos automotores, impondo-se em toda a Europa a redução do teor de chumbo e benzeno na gasolina, estabelecendo-se rígidos controles na fabricação de veículos e na sua utilização. Atenção especial é 
dispensada, no momento, para encontrar soluções que possam impedir o aumento da poluição causada pela emissão de $C F C$ (clorofluorcarbono), tendo em vista a sua interferência na camada de ozônio que circunda o nosso planeta, cuja diminuição tem provocado a previsão de terríveis consequências para a vida na Terra em virtude do aquecimento que provocam na atmosfera. (Raphäel Romi, "L'Europe et la protection juridique de l'environnement" Victoires Editions, Paris, 1990, pp. 33 e $35)$.

4. A poluição por resíduos sólidos.

\subsection{Os resíduos sólidos:}

De todas as substâncias poluentes que hoje merecem a atenção do legislador no sentido de se conseguir a melhoria da qualidade de vida que enseje a todos um ambiente saudável, os resíduos sólidos têm sido pouco considerados, embora o seu volume cresça progressivamente com o crescimento demográfico e o conseqüente aumento do consumo.

Não se dispersando, como os poluentes do ar e da água, nem por isso são menos nocivos ao homem e aos outros seres da natureza, uma vez que permanecem no solo, muitas vezes a céu aberto ou em aterros sanitários, contribuindo para a proliferação de insetos e outros animais daninhos, agentes propagadores de moléstias ou outros efeitos ligados à natureza das substâncias lançadas fora ou abandonadas de forma irregular e irresponsável.

Esclarece Paulo Affonso Leme Machado que, da maneira como o entendemos no Brasil, o termo resíduo sólido significa "lixo, refugo e outras descargas de matérias sólidas, incluindo as provenientes de operações industriais e agricolas e de atividades da própria comunidade, mas não inclui materiais sólidos ou dissolvidos nos esgotos domésticos ou outros significativos poluentes existentes nos recursos hidricos, tais como a lama, residuos sólidos dissolvidos ou suspensos na água encontrados nos efluentes industriais, e materiais dissolvidos nas correntes de irrigação ou outros poluentes comuns da água" (ob. cit., p. 301).

Conceituação mais ampla é dada pela Lei japonesa n. 137/70, a qual abrange "refugos de pequeno e grande porte, cinza, lama, excreções humanas, resíduos de óleo, resíduos alcalinos e ácidos, carcaças e outras asquerosas e desnecessárias matérias as quais estejam no estado sólido ou líquido" 
A questão assume maior gravidade pelo aumento de substâncias químicas, pesticidas e outros produtos tóxicos, de uso freqüente e indiscriminado, sem que se faça o controle de seus resíduos, incluindo-se aí os das substâncias radioativas, que já produziram exemplos de perigosas consequiências do descaso na sua manipulação por pessoas desavisadas, como foi o caso da contaminação por césio, ocorrida em Goiás há alguns anos, pela manipulação de objetos encontrados ao abandono.

Por serem essas questões matérias que afetam a saúde pública, a competência para a fixação das diretrizes gerais é federal, de acordo com a nossa Constituição, sendo também acolhida a competência supletiva dos Estados, atribuindo-se por sua vez aos Municípios a execução das tarefas de limpeza pública, que compreendem a coleta, o transporte e a disposição final dos resíduos sólidos, problemas da maior importância para a conservação de um meio ambiente sadio e equilibrado, que devem merecer toda a atenção da legislação a seu respeito.

\subsection{Na legislação anterior:}

\subsubsection{Na Lei das Contravenções Penais (Decreto-lei n. 3.688/41).}

Na ausência de um tipo penal adequado para a incriminação dessa modalidade de poluição, e com algum esforço de interpretação, pode ser considerada aplicável a figura prevista no art. 37 da Lei das Contravenções Penais intitulada arremesso ou colocação perigosa, que na verdade não é adequada para solucionar convenientemente os problemas já mencionados, mas surgia como a sua única possibilidade em época pregressa. Esse artigo dispõe:

"Arremessar ou derramar em via pública, ou em lugar de uso comum, ou de uso alheio, coisa que possa ofender, sujar ou molestar alguém: Pena Multa.

Parágrafo único - Na mesma pena incorre aquele que, sem as devidas cautelas, coloca ou deixa suspensa coisa que, caindo em via pública ou em lugar de uso comum ou de uso alheio possa ofender, sujar ou molestar alguém"

Não é necessário que tenha havido o incômodo, a ofensa, ou que alguém tenha sido atingido, bastando a possibilidade da ocorrência dessas circunstâncias por qualquer matéria, mesmo que não seja intrinsecamente suja ou imundície. 
Analisando a objetividade jurídica dessa infração, Bento de Faria argumenta que a ofensa, na hipótese, não se refere unicamente ao perigo contra a integridade física, mas a um conceito mais amplo que inclui além da tranqüilidade das pessoas, expressas pelo verbo "molestar" também o decoro público ("Das Contravenções Penais", Rio de Janeiro, Record Editora, 1958, p. 128). Mais apropriado será, na verdade, incluir no conceito o bem jurídico "meio ambiente" de uso comum do povo e essencial à sadia qualidade de vida, segundo a norma constitucional atual.

A incriminação expressa nesse tipo contudo abrange somente uma pequena parcela do problema da poluição causada por resíduos sólidos, uma vez que basicamente se destina a coibir condutas, embora bastante generalizadas e de ocorrência freqüente, como as de lançar restos de varredura, pontas de cigarro, restos de plantas e comidas, embalagens, detritos de frutas e até excrementos ou papel usado, normalmente arremessadas pela população nas vias e logradouros públicos bem como nas áreas internas dos edifícios e nas praças esportivas.

Assiste razão a José Duarte quando afirma que a contravenção em exame "tem, na sua função eminentemente preventiva, uma função educativa $e$ disciplinadora: ajusta o indivíduo a uma conduta que satisfaz às aspirações comuns dos associados e reduz consideravelmente o coeficiente das ações mais graves, danosas e nocivas" (ob. cit., p. 402). Esse é o sentido que também podemos assinarthe na defesa do meio ambiente.

4.2.2. Na legislação ambiental.

A importância dessas questões é aferida pela instituição de uma Politica Nacional de Saneamento, formulada em harmonia com a Política Nacional de Saúde, na Lei n. 5.318/67, que compreende o conjunto de diretrizes administrativas e técnicas destinadas a fixar a ação governamental no campo do saneamento.

Essa Política, nos termos do art. $2^{\circ}$ da referida Lei, abrange:

a. saneamento básico (abastecimento de água, sua fluoretação e destinação dos dejetos);

b. esgotos pluviais e drenagem;

c. controle da poluição ambiental, inclusive do lixo;

d. controle das modificações artificiais das massas de águas; 
e. controle de inundações e erosões.

Uma parcela dessas questões refere-se à atividade industrial (zoneamento e dejetos industriais), outra às atividades urbanas (lixo) e outra às atividades agrícolas (poluição por agrotóxicos ou pesticidas).

Para o zoneamento industrial nas áreas críticas de poluição foram formuladas diretrizes básicas pela Lei n. $6.803 / 80$, no seu art. $2^{\circ}$, que reservou uma zona "estritamente industrial" para a instalação de estabelecimentos "cujos resíduos sólidos, líquidos e gasosos, ruídos, vibrações, emanações e radiações possam causar perigo à saúde, ao bem-estar e à segurança das populações, mesmo depois da aplicação de métodos adequados de controle e tratamento de efluentes, nos termos da legislação vigente"

A poluição industrial já havia merecido anteriormente uma regulamentação jurídica através do Decreto-lei n. 1.413/75, que estabeleceu para as indústrias instaladas ou a se instalarem no território nacional a obrigação de promover as medidas necessárias para prevenir ou corrigir os inconvenientes e prejuízos da poluição e da contaminação do meio ambiente, a serem definidas pelos órgãos federais competentes. Na sua regulamentação, pelo Decreto n. 76.389/75, atribuiu-se à SEMA (Secretaria Especial do Meio Ambiente, órgão do Ministério do Interior) a competência para propor critérios, normas e padrões visando a evitar e corrigir os efeitos danosos da poluição industrial. Esta foi conceituada, no art. $1^{\circ}$, como "qualquer alteraçâo das propriedades fisicas, químicas ou biológicas do meio ambiente, causadas por qualquer forma de energia ou de substância sólida, líquida e gasosa, ou combinação de elementos despejados pelas indústrias, em niveis capazes direta ou indiretamente de:

I- prejudicar a saúde, a segurança e o bem-estar da população;

II criar condições adversas às atividades sociais e econômicas;

III ocasionar danos relevantes à flora, à fauna e a outros recursos naturais"

Nas atividades urbanas o maior agente poluidor é o lixo, que foi objeto de uma recomendação na Lei n. 2.312/54, a qual estabeleceu normas gerais sobre defesa e proteção à saúde, prescrevendo no seu art. 12: "A coleta, o transporte e o destino final do lixo deverão processar-se em condições que não tragam inconvenientes à saúde e ao bem-estar público, nos termos da regulamentação a ser baixada" 
Essa regulamentação, porém, ao ser baixada pelo Decreto n. 49.974-A de 1961, denominado Código Nacional de Saúde apenas repetiu os termos do artigo citado acima, instando as indústrias já instaladas ou por instalar a submeter à autoridade competente, nos devidos prazos, os seus planos de lançamento de resíduos líquidos, gasosos e sólidos.

Posteriormente, considerando a importância do lixo e dos resíduos sólidos, provenientes de diversas atividades humanas que poluem o solo, o ar e a água, e a contínua deterioração das áreas utilizadas para depósitos ou vazadouros de lixo ou resíduos sólidos, e objetivando extinguir os lixões, vazadouros ou depósitos de lixo a céu aberto no menor prazo possível, no interesse da qualidade de vida, a Portaria n. 053/79, do ministro do Interior, estabeleceu que os projetos específicos de tratamento e disposição de resíduos sólidos, bem como a fiscalização de sua implantação, operação e manutenção ficariam sujeitos à aprovação do órgão estadual de controle da poluição e da preservação ambiental e determinou basicamente que:

1 O lixo "in natura" não deve ser utilizado na agricultura ou na alimentação de animais.

2 - Os resíduos sólidos de natureza tóxica, bem como os que contém substâncias inflamáveis, corrosivas, explosivas, radioativas e outras consideradas prejudiciais, deverão sofrer tratamento ou acondicionamento adequado, no próprio local de produção, e nas condições estabelecidas pelo órgão estadual de controle da poluição e de preservação ambiental.

3 Os lixos ou resíduos sólidos não devem ser lançados em cursos d'água, lagos e lagoas, salvo na hipótese de necessidade de aterro de lagoas artificiais, com a devida autorização.

4 os resíduos sólidos provenientes de portos e aeroportos deverão ser incinerados nos próprios locais de produção.

5 Todos os resíduos sólidos portadores de agentes patogênicos, inclusive os de estabelecimentos hospitalares e congêneres, assim como alimentos e outros produtos de consumo humanos condenados, deverão ser adequadamente acondicionados e conduzidos em transporte especial e, em seguida, obrigatoriamente incinerados.

6 São excluídos da obrigatoriedade de incineração os resíduos sólidos portadores de agentes patogênicos submetidos a processo de esterilização por radiações ionizantes, em instalações licenciadas pela Comissão Nacional de Energia Nuclear. 
7 - Não devem ser utilizados incineradores de resíduos sólidos em edificações residenciais, comerciais e de prestação de serviços.

8 Os resíduos sólidos ou semi-sólidos de qualquer natureza não devem ser colocados ou incinerados a céu aberto, tolerando-se apenas:

a. a acumulação temporária de resíduos de qualquer natureza em locais previamente aprovados, desde que isso não ofereça riscos à saúde e ao meio ambiente, a critério das autoridades de controle da poluição e de preservação ambiental ou de saúde pública.

b. a incineração de resíduos sólidos ou semi-sólidos de qualquer natureza, a céu aberto, em situações de emergência sanitária.

9 O lançamento de resíduos sólidos no mar dependerá de prévia autorização das autoridades federais competentes.

10 Nos planos e projetos de destinação final de resíduos sólidos devem ser incentivadas as soluções conjuntas para grupos de Municípios, bem como soluções que importem em reciclagem e reaproveitamento racionais desses resíduos.

Essas normas de cunho administrativo têm, como se percebe, um sentido nitidamente preventivo, buscando impedir que o lixo se transforme em real problema sanitário.

Todavia, nos casos extremos caberia a aplicação do tipo penal previsto na Lei n: 6.938/81, com a redação determinada pela Lei n. 7.804/89, a já mencionada poluição em geral ou, como a denomina Gilberto Passos de Freitas, poluição sob qualquer forma, que subsidiariamente era aplicável a qualquer espécie de poluição.

A mesma abrangência possui a figura penal prevista agora na nova lei ambiental que transformou porém essa modalidade de poluição em qualificadora para caracterizar delito mais grave a que se comina pena mais severa.

\subsubsection{Na Nova Lei Ambiental.}

A Lei n. 9.605/98, na tipificação do art. 54 ao mencionar a poluição de qualquer natureza, evidentemente, pretendeu incluir aí a poluição por resíduos sólidos, a ser punida com a pena prevista, se dela resultar, ou puder resultar, danos à saúde humana, ou que provoquem a mortandade de animais ou a destruição significativa da flora, havendo menção também à forma culposa. Todavia foi essa modalidade incluída expressamente entre as circunstâncias que tornam esse delito 
genérico em forma qualificada, à qual se impõe pena mais grave, a qual é determinada nos seguintes casos:

a. se torna uma área, urbana ou rural, imprópria para a ocupação humana;

b. se dificulta ou impede o uso das praias;

c. se ocorre por lançamento de resíduos sólidos, líquidos ou gasosos, ou detritos, óleos ou substâncias oleosas, em desacordo com as exigências estabelecidas em leis ou regulamentos;

d. se alguém deixa de adotar, quando assim o exigir a autoridade competente, medidas de precaução em caso de risco ambiental grave ou irreversível.

Afirmam os comentaristas que a poluição por resíduos sólidos já era objeto de regulamentação jurídica no Direito Romano em que se determinava a responsabilidade de quem colocasse ou pendurasse alguma coisa perigosa ou prejudicial a alguém em lugar por onde habitualmente se passa, conceito acolhido pelo Código Penal italiano vigente, que nos seus arts. 674 e 675 incrimina como contravenções penais o "getto pericoloso di cose" e o "collocamento pericoloso di $\cos e^{\prime \prime}$

A lei francesa é mais explícita e embora considere como contravenção penal, punida apenas com multa, no art. R. 632-1 do atual Código Penal incrimina " $a$ deposição, o abandono ou o arremesso de lixo, dejetos, materiais ou outro objeto, de qualquer natureza, em um lugar público ou privado, com exceção do local designado para esse fim pela autoridade administrativa competente" fazendo menção, no mesmo artigo, à possibilidade de sua imputação às pessoas jurídicas (pessoas morais). Em separado, no art. R. 635-8 pune também com multa " $o$ abandono, arremesso ou colocação de destroços de veículos ou de lixo, dejetos, materiais e outros objetos transportados por um veículo" sem autorização, aplicável às pessoas jurídicas, com o confisco da coisa que serviu para a execução da infração.

Igualmente na Alemanha pune-se "a eliminação de refugos perigosos" seja por que possam conter ou produzir substâncias venenosas ou agentes patogênicos de doenças perigosas para a coletividade e transmissiveis no contacto com homens e animais, seja porque são explosivas, inflamáveis ou radioativas, seja porque são idôneas, pelo tipo, condição ou quantidade, a poluir a água, o ar, o solo ou a produzir alterações prejudiciais. A pena cominada no art. 326 no Código Penal alemão é detentiva até 3 (três) anos ou então pecuniária. 
Paulo Affonso Leme Machado, considerando a impunidade dos poluidores nessa modalidade de ofensa ao meio ambiente, e a inocuidade das medidas administrativas que raramente punem os ilícitos verificados, declarou ser favorável a um reforço da punição penal para a sua apuração judicial, considerandose os efeitos preventivos que isso ocasionaria e a sua conveniência social, face às necessidades dos conglomerados humanos e aos maus hábitos da população nacional. Chegou mesmo a propor a redação de um delito de "poluição por resíduos sólidos", definindo a conduta como "lançar ou depositar residuo sólido, em propriedade alheia ou privada, sem observância das prescrições legais ou regulamentares", para a qual propunha como sanção a pena de reclusão até três anos e multa (ob. cit., p. 310).

De qualquer modo, seja qual for a fórmula adotada, o tipo penal terá de adequar-se às prescrições federais, estaduais e municipais, que encontrarão dessa forma a sua mais completa efetivação, como complemento da norma penal em branco que o constitui.

\section{A poluição por pesticidas.}

\subsection{Os pesticidas:}

Sob várias denominações, alguns compostos químicos vêm sendo utilizados para controlar ou eliminar pragas, fungos, insetos daninhos que infestam certas áreas urbanas, os campos e as vegetações em geral. A sua utilidade se faz presente sobretudo nas plantações, seja para a própria subsistência do lavrador, seja para a comercialização das safras agrícolas, atividade essencial para a economia do país e da população em geral.

Com o nome de pesticidas são fabricados vários produtos que abrangem inseticidas, fungicidas, formicidas, herbicidas e outros. Os que são utilizados especificamente na agricultura costumam ser chamados defensivos agrícolas ou agrotóxicos.

O seu uso intenso ou de forma inapropriada pode causar danos terríveis ao meio ambiente, prejudicando ou destruindo o equilíbrio ecológico natural e a propagação das espécies. Os cientistas têm também apontado outro perigo na sua utilização, mesmo normal, que é a persistência de sua toxicidade nos resíduos, com efeitos imprevisíveis em mutações genéticas ainda não muito conhecidas. 
Por outro lado, muitos deles têm sido agentes eficientes no combate a certas pragas e insetos transmissores de moléstias graves, pelo que têm sido úteis na área da saúde pública, além de contribuir para a melhoria da qualidade dos produtos agrícolas, elevando a qualidade dos alimentos consumidos no país.

É inegável porém que o uso dos agrotóxicos e pesticidas em geral precisa ser criteriosamente controlado para evitar os desastres ecológicos ou o desequilíbrio dos ecossistemas pela formação de raças mais resistentes, o depósito indiscriminado de resíduos, e sobretudo o perigo que representam para a saúde e a vida de todos os seres vivos quando atingidos pelos seus efeitos altamente tóxicos, muitas vezes em decorrência de manipulação inadequada. Tal se deve sobretudo à carência de conhecimentos técnicos dos agricultores ou à omissão e negligência dos que se utilizam dos agrotóxicos e biocidas na proteção de suas lavouras, florestas ou animais, causando danos graves e às vezes irreversíveis aos mesmos ou ao meio ambiente, embora existam alertas dos produtores e das entidades agrícolas quanto às cautelas recomendáveis na sua utilização.

Por isso essas substâncias têm o seu uso e a sua elaboração regulados por normas técnicas especiais, que abrangem desde a instalação e o funcionamento das indústrias de pesticidas, a sua fabricação, o seu registro nas repartições competentes, a sua comercialização e, finalmente, a sua utilização.

Essas normas intensificaram-se a partir de 1970 com as necessidades surgidas com a moderna tecnologia de plantio e o aperfeiçoamento dos produtos auxiliares da atividade agrícola, complementando as normas, que haviam sido inovadoras à sua época, do Decreto n. 24.114/34 (Regulamento de Defesa Sanitária Vegetal), o qual prescrevia sanções administrativas, mais tarde reforçadas por legislação penal.

Com a promulgação da Constituição Federal de 1988 revela-se novamente a preocupação com essa modalidade de poluição quando no art. 225 , que orienta a proteção a ser dada ao meio ambiente ecologicamente equilibrado, o seu $\S$ $1^{\circ}$. determina, no inciso V, que incumbe ao Poder Público "controlar a produção, a comercialização e o emprego de técnicas, métodos e substâncias que comportem risco para a vida, a qualidade de vida e o meio ambiente" 


\subsection{Na legislação anterior:}

As normas que regem a matéria prescrevem para a produção e venda dos pesticidas em geral o seu registro ou no Ministério da Saúde, se destinados ao uso doméstico, ou no Ministério da Agricultura se destinados à agropecuária.

$\mathrm{Na}$ primeira hipótese, o Decreto n. 67.112/70 estabeleceu as normas para a fabricação e a venda de produtos saneantes entendidos como tais, segundo a conceituação legal, as substâncias ou os preparados destinados à higienização, desinfecção ou desinfestação, inclusive no tratamento da água e do solo. Esses produtos, para os efeitos legais, são classificados em:

a. domissanitários os que se destinam à aplicação nos domicílios, ambientes coletivos, públicos ou de uso comum, ou para tratamento da água;

b. fitossanitários os que se destinam à aplicação em vegetais e seus produtos e ao tratamento do solo.

c. zoossanitários os que se destinam à aplicação em animais.

$O$ registro dos produtos domissanitários, que deve ser efetuado no Ministério da Saúde, é regulado pela Lei n. 6.360/76, tendo como pressuposto a ausência de qualquer possibilidade de risco à saúde humana e à saúde dos animais domésticos de sangue quente "nas condições de uso previstas". O dos produtos fitossanitários e zoossanitários, efetuado no Ministério da Agricultura, deve obedecer a várias exigências previstas no Decreto n. 67.112/70, elaboradas com o fim primordial de proteger a saúde humana. Serão então classificados em: praticamente não-tóxicos, pouco tóxicos, medianamente tóxicos e altamente tóxicos, sendo as duas últimas categorias de venda controlada, segundo a Portaria n. 07/81 do ministro da Agricultura. Na sua fabricação, a fórmula dos pesticidas deverá atender às precauções necessárias relativas ao seu manuseio e às medidas terapêuticas na eventualidade de um acidente, visando sempre a preservação da vida e da saúde humana.

Em 1977 foi criada a Comissão de Defensivos Agrícolas, órgão consultivo da Divisão de Defesa Sanitária Vegetal, do Ministério da Agricultura, cuja finalidade principal é a de sugerir medidas e providências relativas às implicações do uso de defensivos sobre a saúde pública e o meio ambiente.

Relativamente às normas que regulamentam o uso de pesticidas, levando em consideração o perigo potencial que essas substâncias representam para o meio ambiente, são os Estados que estabelecem os requisitos exigíveis e examinam 
os indícios de que ocorrerá ou-não o lançamento de poluentes na água, no ar ou no solo. Em São Paulo o assunto é objeto de duas leis: a Lei estadual n. 997/76 e a Lei n. 1.172/76, sendo imprescindível a licença da Cetesb, sob pena de nulidade do ato.

As indústrias funcionam sob o regime de licença, do Ministério da Saúde ou do Ministério da Agricultura, renovável anualmente, ficando sujeitas à inspeção, sob pena de interdição.

A fiscalização, prevista no citado Regulamento de Defesa Sanitária Vegetal, ainda em vigor apesar da inoperância das multas em bases fixas, pode aplicar sanções administrativas de apreensão, inutilização e interdição de produtos nocivos ou que não tenham sido registrados.

Toda essa legislação havia construído um instrumental razoável destinado a fornecer, tanto quanto possível, um manancial de medidas protetoras da saúde humana e do meio ambiente, com a intimidação dos violadores das normas referentes aos pesticidas. Restava porém impor algumas regras que impedissem a livre comercialização desses produtos e o seu uso generalizado por pessoas despreparadas ou sem o emprego das cautelas necessárias.

Tal vazio foi preenchido com a promulgação da Lei n. 7.802/89, conhecida como a "Lei dos Agrotóxicos" que regulou as atividades nesse setor e estabeleceu a incriminação de algumas condutas consideradas perigosas sobretudo para a vida e a saúde humana.

5.3. Na Lei dos Agrotóxicos:

Além de regular a matéria de agrotóxicos e criminalizar condutas, a Lei n. 7.802/89 conceitua o que considera como tal, assim como os seus componentes e princípios ativos. Segundo o seu art. $2^{\circ}$, agrotóxicos e afins são:

a. "os produtos e os agentes de processos fisicos, químicos ou biológicos, destinados ao uso nos setores de produção, no armazenamento e beneficiamento de produtos agrícolas, nas pastagens, na proteção de florestas nativas ou implantadas, e de outros ecossistemas e também de ambientes urbanos, hidricos $e$ industriais, cuja finalidade seja alterar a composição da 
flora ou da fauna, a fim de preservá-las da ação danosa de seres vivos considerados nocivos;

b. substâncias e produtos, empregados como desfolhantes, dessecantes, estimuladores e inibidores do crescimento"

Quanto aos seus componentes ou princípios ativos são eles os produtos técnicos, suas matérias-primas, os ingredientes inertes e aditivos usados na fabricação de agrotóxicos e afins.

Inseridos entre inúmeras disposições existentes nessa lei a respeito de registro de agrotóxicos, pesquisas e experimentação, requisitos para a comercialização, etc., existem dois tipos penais referentes à matéria: um, de desobediência às exigências prescritas, e outro de omissão de medidas de proteção:

Art. 15 - "Aquele que produzir, comercializar, transportar, aplicar ou prestar serviço na aplicação de agrotóxicos, seus componentes e afins, descumprindo as exigências estabelecidas nas leis e nos seus regulamentos ficará sujeito à pena de reclusão de 2 (dois) a 4 (quatro) anos, além da multa. Em caso de culpa será punido com pena de reclusão, de $I$ (um) a 3 (três) anos, além da multa."

Objetivando a proteção ambiental, pune-se a ação aí descrita pela situação de perigo em que coloca toda a coletividade ao contrariar as prescrições legais e regulamentares sobre a matéria. Estas estão em parte na própria Lei $\mathrm{n}$. $7.802 / 89$, já que a mesma estabelece uma série de requisitos a serem observados a respeito das formalidades de registro, a natureza e a forma das embalagens, os dados que devem constar dos rótulos, inclusive informações relativas ao perigo potencial, que será conteúdo obrigatório de sua propaganda comercial. Determina também que a venda dos agrotóxicos somente será feita através de receituário próprio, fornecido por profissionais legalmente habilitados, a não ser em casos excepcionais, previstos na regulamentação dessa Lei.

É de observar-se que a pena privativa de liberdade prevista para a modalidade culposa inova em matéria penal, atribuindo como espécie a reclusão, quando tradicionalmente nos delitos culposos, pela menor quantificação da sanção e pela natureza menos reprovável do ilícito, é usual a pena de detenção. 
Art. 16 - "O empregador, profissional responsável ou prestador de serviço que deixar de promover as medidas necessárias de proteção à saúde e ao meio ambiente estará sujeito à pena de reclusão de 2 (dois) a 4 (quatro) anos, além da multa. Em caso de culpa, será punido com pena de reclusão de I (um) a 3 (três) anos, além da multa."

As categorias mencionadas têm, pois, o dever de maior cuidado e diligência na orientação ou execução de tarefas suas ou de seus subordinados que exigirem o manuseio das substâncias tóxicas para o serviço que realizam, devendo a sua atuação pautar-se pelas medidas prescritas nas leis, regulamentos, portarias e outros atos administrativos, além daquelas que, mesmo não-escritas, forem julgadas necessárias à proteção da saúde e o meio ambiente segundo o senso comum.

É delito omissivo, de desobediência a preceitos imperativos implícitos, que o agente descumpre por inação, colocando em risco toda a coletividade pelo perigo que isso representa aos bens jurídicos tutelados. Mas o tipo penal é excessivamente aberto, possibilitando formas ilimitadas de conduta omissiva, o que prejudica a sua aplicação, ao invés de facilitá-la.

Considerando a objetividade jurídica das normas penais nessa matéria, entende Paulo Affonso Leme Machado ser também aplicável o art. 132 do Código Penal (periclitação da vida ou da saúde), quando a ocorrência não puder ser tipificada nas duas figuras criminais citadas. Quando da aplicação do pesticida resultar resíduos nos alimentos acima dos limites de tolerância, também o art. 279 do Código Penal (substância avariada), que depois foi revogado pela Lei n. 8.137/90, que no inciso IX do seu art. $7^{\circ}$ considera crime contra as relações de consumo "vender, ter em depósito para vender ou expor à venda ou, de qualquer forma, entregar matéria-prima ou mercadoria, em condições impróprias ao consumo."

Evidentemente também aqui, conforme o caso, seria possível utilizarse da figura criminal prevista no art. 15 da Lei n. 6.938/81, o delito de poluição em geral, que era a forma subsidiária de suprir-se a proteção penal ambiental em todos os casos de perigo à incolumidade humana, animal ou vegetal, mas que agora encontra-se revogada pelas novas disposições da Lei n. 9.605/98, que também abrange, em conceituação mais ampla, as figuras anteriormente previstas na Lei dos Agrotóxicos. 


\subsection{Na Nova Lei Ambiental:}

A Lei n. 9.605/98, apesar de apresentar também uma incriminação relativa à poluição em geral, referida no art. 54 como poluição de qualquer natureza, considerando o caso específico dos pesticidas e outras substâncias nocivas à saúde e ao meio ambiente incluiu as condutas anteriormente tipificadas na Lei dos Agrotóxicos, acima examinada, que ficam pois revogadas, alargando o conceito anteriormente fixado para estender a proteção legal também contra as substâncias nucleares ou radiotivas, inexistente na legislação anterior.

Dispõe o seu art. 56:

"Produzir, processar, embalar, importar, exportar, comercializar, fornecer, transportar, armazenar, guardar, ter em depósito ou usar produto ou substância tóxica, perigosa ou nociva à saúde humana ou ao meio ambiente, em desacordo com as exigências estabelecidas em leis ou nos seus regulamentos: Pena reclusão de um a quatro anos, e multa.

$\S 1^{\circ}$ Nas mesmas penas incorre quem abandona os produtos ou substâncias referidos no caput ou os utiliza em desacordo com as normas de segurança.

$\S 2^{\circ}$ Se o produto ou a substância for nuclear ou radioativa, a pena é aumentada de um sexto a um terço.

$\S 3^{\circ}$ Se o crime é culposo: Pena - detenção, de seis meses a um ano, e multa."

Sempre constituiu uma preocupação do legislador, que já transparecia nos delitos comuns, a situação de perigo à vida e à saúde das pessoas em geral pelo consumo de produtos que tenham a sua qualidade alterada de alguma forma, inclusive por substâncias que tenham sido acrescentadas à produção dos mesmos, tais como fertilizantes ou pesticidas usados na lavoura, e que tenham deixado resíduos nocivos.

Eram normas porém inadequadas para a aplicação nesses casos específicos que a lei atual contempla, como já o fizera a Lei n. 7.802/89 referindo-se a agrotóxicos, seus componentes e afins, ampliando ainda mais a proteção legal ao 
estendê-la para produtos ou substâncias tóxicas em geral, aí compreendidas as nucleares e radioativas, anteriormente ignoradas.

Nesse sentido a legislação comunitária européia já vinha apresentando desde 1976 diretivas fixando os limites máximos dos resíduos de certos produtos antiparasitários para a aplicação em diversas frutas e legumes, que passaram a nortear desde então a política agrícola comum, com as alterações acrescentadas em 1981 e 1982, sendo em 1986 estendidos aos cereais e outros gêneros de origem animal.

Segundo informa Raphäel Romi ("L'Europe et la protection juridique de l'environnement" Victoires Ed., Paris, 1990, p. 43), os países europeus têm, na sua maioria, adotado a classificação dos pesticidas sugerida pela CEE, bem como a proibição por ela recomendada, da oferta para consumo e da utilização de produtos compostos por mercúrio e os organoclorados persistentes como o DDT. Para citar apenas um exemplo, na França vigora uma legislação severa a respeito de substâncias e preparações destinadas à agricultura, a nível administrativo e a nível penal, que leva em consideração os perigos para o homem, para a fauna e para a flora, causados pela dispersão de produtos químicos nas práticas agrícolas, os quais, embora aplicados no solo ou em zonas restritas, podem, pela ação do vento e da chuva, serem levados para fora da superfície tratada, causando assim a poluição das águas e das terras, destruindo a vida animal e vegetal. Basicamente, os produtos para uso agrícola são objeto de duas leis: uma, relativa a pesticidas (Lei de 02.11.43, reformulada em 22.12.72), e outra relativa a fertilizantes e suportes de cultura (Lei de 13.07.79). Repousam elas sobre os mesmos princípios, a saber: todos os produtos devem ser autorizados previamente para a venda; sua publicidade é estritamente regulamentada; seu emprego pelo usuário póde ser submetido a restrições. Todas as prescrições e proibições resultantes desses princípios são sancionadas penalmente, com maior rigor para as ações fraudulentas.

$\mathrm{Na}$ atual lei ambiental brasileira o tipo penal remete às normas e exigências estabelecidas sobre a matéria em outras leis ou nos seus regulamentos, entre as quais figuram inegavelmente aquelas estabelecidas na Lei n. 7.802/89 para a pesquisa, a experimentação, a produção, a embalagem e rotulagem, o transporte, o armazenamento, a comercialização, a propaganda comercial, a utilização, a importação, a exportação, o destino final dos resíduos e embalagens, o registro, a classificação, o controle, a inspeção e a fiscalização dos agrotóxicos, seus componentes e afins, que não foram revogadas pela lei mais recente, a qual apenas 
definiu as infrações penais e administrativas nessa matéria e as suas respectivas sanções.

Por outro lado, a maior amplitude do objeto material do delito previsto no art. 56 e seus parágrafos, que abrange todo e qualquer produto ou substância tóxica que seja perigosa ou nociva à saúde humana ou ao meio ambiente, justifica a configuração desse tipo penal como um crime de desobediência a normas legais ou regulamentares, que se revela o mais adequado para a proteção penal do meio ambiente contra as várias modalidades de poluição.

6. Outras modalidades: poluição sonora e poluição visual.

Cabem ainda na categoria da degradação ambiental ensejada pelas atividades humanas que prejudicam a saúde e o bem-estar da população, ou a qualidade de vida mencionada na norma constitucional como um direito do homem para o pleno desenvolvimento da sua personalidade e dos seus fins na sociedade, a serem transmitidas para as futuras gerações, duas situações que têm se tornado exacerbadas na vida das grandes cidades, exigindo a interferência da regulamentação jurídica para solucionar os problemas mais graves. Trata-se dos incômodos causados pelos ruídos excessivos, que podem tornar-se insuportáveis e maléficos à saúde, com resultados apreciáveis no plano físico e no plano mental e reflexos na produtividade do trabalho e no comportamento social, a que se convencionou chamar poluição sonora, e, por outro lado, das condições abusivas de interferência no ambiente artificial ou cultural, sobretudo nas cidades, que interferem na estética e na qualidade das edificações, ruas e praças públicas, modificando a paisagem natural ou urbana e os conjuntos arquitetônicos que compõem o nosso patrimônio cultural, essencial igualmente à nossa historia e à nossa sobrevivência como nação, designadas metaforicamente como poluição visual.

Num e noutro caso as sanções meramente administrativas têm se revelado ineficazes e os abusos verificados na prática autorizam a intervenção da sua incriminação pelas normas penais no sentido de garantir maior proteção à qualidade de vida, atuando também preventivamente para impedir a degradação ambiental das cidades e dos espaços públicos e a sua correta fruição pelo homem. 


\subsection{A poluição sonora:}

Espécie insidiosa de poluição, nociva em função da sua duração e intensidade, bem como da sua acostumação e repetição, tem sido a poluição sonora objeto de algumas medidas protetoras instituídas em vários países para garantir o respeito e a aplicação de normas editadas para enfrentar as suas consequiências, que podem referir-se à tranqüilidade e ao sossego, mas também à saúde e à integridade física da população em geral.

As principais fontes dessas ondas sonoras que se propagam pelo ar, e que são designadas ruídos, normalmente são as instalações industriais e a circulação de veículos em geral, mas podem compreender outras atividades, como a construção civil, os eventos festivos ou meramente ruidosos de vizinhos ou grupos de indivíduos reunidos, o sistema de som de bares ou casas noturnas, e até mesmo a venda ou distribuição de certos produtos anunciados por sons exagerados ou irritantes.

Michel Prieur define o ruído como toda sensação auditiva desagradável, incômoda ou todo fenômeno acústico que produz essa sensação ("Droit de l'environnement" $2^{\text {a }}$ ed., Dalloz, Paris, 1991, p. 488). Acrescenta ainda que sendo o ruído por natureza um fenômeno subjetivo, já se sustentou que consistiria em todo som não-desejado, uma vez que o ruído é sentido de modo diferente não-somente em função do seu real nível acústico, mas também em função do contexto, do estado de saúde e do equilíbrio nervoso daquele que constitui a sua vítima.

Acrescenta Günter Fellenberg que apesar da interpretação ser subjetiva existe um limite fisiológico máximo acima do qual a onda sonora provoca sensação de dor. Como a intensidade do som é suportada de maneira variável, conforme o intervalo da freqüência, o limite auditivo dependerá dessa relação ("Introdução aos problemas da poluição ambiental" trad. de Juergen Heinrich Maar, São Paulo, Springer/EDUSP. 1980, p. 189).

Existem padrões de avaliação no sentido de orientar a regulamentação dos ruídos abusivos, que são constituídos por medidas físicas de determinação da intensidade do som. O mais comum atualmente é o decibel (dB), unidade que exprime uma relação entre potências sonoras, obtida pela integração da intensidade do som sobre uma superfície que envolve a fonte sonora.

Sabe-se, além disso, que com emissões sonoras prolongadas, de níveis de freqüência de 120 a $130 \mathrm{~dB}$, podem manifestar-se no homem distúrbios nervosos, 
insônia e, não-raro, enfartes. Se os sons forem desagradáveis e indesejáveis, neuroses podem ser provocadas com intensidades sonoras mais baixas, principalmente se a fonte não puder ser suprimida, sentindo-se o indivíduo indefeso perante o ruído (por exemplo, o barulho no trânsito, o rádio em alto volume, o instrumento musical do vizinho, etc.).

Daí a importância de se estabelecerem os limites de intensidade do som, variáveis e adaptados às circunstâncias da vida diária, como fez, aliás, a legislação brasileira pertinente, incluindo os níveis excessivos de sons e ruídos entre aqueles sujeitos ao Controle da Poluição do Meio Ambiente. A matéria foi objeto da Portaria GM/092, do ministro do Interior, onde se declara que "a emissão de sons e ruidos em decorrência de quaisquer atividades industriais, comerciais, sociais ou recreativas, inclusive as de propaganda, obedecerá ao interesse da saúde, da segurança e do sossego público, aos padrões, critérios e diretrizes estabelecidos nesta Portaria"

A seguir são escalonados os limites, em decibéis, acima dos quais os sons e ruídos são considerados prejudiciais à saúde, à segurança e ao sossego público, abrangendo os diversos setores em que essa emissão seja possível, desde os produzidos por veículos automotores ou no interior dos ambientes de trabalho até os produzidos nos recintos fechados em geral ou na execução de projetos de construção ou de reforma de edificações.

Apesar disso tudo, a legislação brasileira não seguiu a tendência, hoje existente a nível internacional, de estabelecer para a poluição sonora o mesmo sistema de proteção jurídica com o qual são tutelados os interesses relevantes da pessoa humana na área da saúde pública. Considerando os efeitos deletérios já mencionados, a matéria ainda não encontrou um tratamento legal à altura de sua importância, sobretudo na área penal, em que apenas um dispositivo da Lei das Contravenções Penais tem aplicação, em algumas hipóteses apenas de todas as que podem ocorrer, sob a forma de "perturbação do trabalho ou do sossego alheios"

Com efeito, dispõe o art. 42 daquele diploma legal:

"Perturbar alguém, o trabalho ou o sossego alheios:

I - com gritaria ou algazarra;

II - exercendo profissão incômoda ou ruidosa, em desacordo com as prescrições legais;

III abusando de instrumentos sonoros ou acústicos; 
$I V$ - provocando ou não procurando impedir barulho produzido por animal de que tem a guarda.

Pena - prisão simples, de 15 (quinze) dias a 3 (três) meses, ou multa"

Esse dispositivo tem sido aplicado algumas vezes, estabelecendo-se pela jurisprudência a interpretação de seus termos vagos ou imprecisos, no sentido de ser exigível a análise da duração e da intensidade do ruído, conforme as circunstâncias de lugar e de tempo, para que se tenha certeza de que houve excesso quanto aos limites de conveniência ou da tolerância alheia, ou daquilo que foi estabelecido em outras normas disciplinadoras da matéria, muitas delas objeto de regulamentação pelas municipalidades, seja no Código de Obras local ou em outras posturas.

José Duarte adverte para a existência de "ruidos autorizados", como os provenientes de celebrações cívicas ou festas populares, de que são exemplo no Brasil o Carnaval, o "Bumba-meu-boi" etc., considerados divertimentos lícitos, ficando então afastada a contravenção penal, o que também deve ocorrer na hipótese de uma algazarra provocada por uma rixa na rua, cuja acidentalidade é inerente ao próprio fato e cujo incômodo será absorvido na repressão do fato mais grave ("Comentários à Lei das Contravenções Penais", Rio de Janeiro, Rev. Forense Ed., 1944, p. 447).

Reconhecendo a inadequação da figura contravencional para a ampla defesa dos bens jurídicos ambientais contra os ruídos excessivos, que não se limitam à perturbação da saúde e da tranqüilidade, mas podem causar sérios danos à saúde humana, conforme já se comentou, a Lei n. 9.605/98 incluiu entre as modalidades de poluição uma conduta de desobediência a prescrições legais e regulamentares que se destinava a fornecer maior amplitude e maior abrangência à proteção penal nessa matéria.

Com efeito, assim dispunha o seu art. 59, que foi afinal vetado pelo presidente da República: "Produzir sons, ruidos ou vibrações em desacordo com as prescrições legais ou regulamentares, ou desrespeitando as normas sobre emissão e imissão de ruidos e vibrações resultantes de quaisquer atividades": Pena detenção, de três meses a um ano, e multa."

$\mathrm{Na}$ versão oficial das razões dos vetos foi declarado que esse artigo contemplava hipótese já existente na Lei das Contravenções Penais, sob a forma de perturbação do trabalho ou do sossego alheio "de forma mais apropriada e 
abrangente" para a punição da poluição sonora... O absurdo da justificativa, além de assegurar a permanência em vigor do art. 42 da Lei das Contravenções Penais, leva tranqüilamente à aplicação do tipo penal previsto no art. 54 da Nova Lei Ambiental para certos casos de produção de ruídos, uma vez que se aplica à causação de poluição de qualquer natureza "em niveis tais que resultem ou possam resultar em danos à saúde humana".

De qualquer modo, a matéria está ainda longe de ter alcançado soluções satisfatórias e aguarda a atenção do legislador para que sejam tomadas as medidas repressivas e preventivas adequadas a solucionar os problemas causados pelos ruídos excessivos, a exemplo do que se fez em outras legislações, como por exemplo a francesa, que regulamentou apropriadamente a emissão de ruídos e vibrações por fontes fixas ou móveis, estabelecendo os limites dos níveis sonoros suportáveis pelo público provenientes das vias públicas ou das instalações industriais, canteiros de obras ou de construção civil, e do tráfego aéreo inclusive, estabelecendo obrigações legais cuja observância é assegurada por sanções penais. Especial atenção é dada aos ruídos proveniente do trânsito de veículos automotores, para cuja fabricação se fixam regras a fim de torná-los mais silenciosos, seguindo orientação que é hoje mundial.

\subsection{A poluição visual:}

A matéria atinente à poluição visual insere-se no âmbito da preservação dos bens culturais, que compõem o patrimônio cultural brasileiro, segundo a ampla conceituação do art. 216 da Constituição Federal, que abrange nãosomente os sítios de valor histórico, paisagístico, artístico, arqueológico, paleontológico, ecológico e científico, mas também os conjuntos urbanos, "portadores de referência à identidade, à ação, à memória dos diferentes grupos formadores da sociedade brasileira"

$\mathrm{Na}$ legislação anterior a única forma existente de proteção dos bens culturais era proporcionada pelo Código Penal, que no seu art. 165 incriminava o dano em coisa de valor artístico, arqueológico ou histórico, desde que fosse tombada.

A Lei n. 9.605/98 modificou o tratamento dado a essa questão incluindo uma seção especial para os crimes contra o ordenamento urbano $e o$ patrimônio cultural, com aplicação mais abrangente, que prescinde do ato de 
tombamento, entre os quais figura a conduta causadora da poluição visual, no seu art. 65, sob a forma de "pichar, grafitar ou por outro meio conspurcar edificação ou monumento urbano".

Esse tipo penal era inexistente na legislação brasileira anterior, a não ser por momentânea inclusão em Lei Eleitoral já revogada, que incriminava a propaganda eleitoral abusiva sob a forma de cartazes e propaganda colocados nas vias e logradouros públicos, que enfeiavam a cidade e desnaturavam as finalidades e o aspecto dos monumentos e edificações.

Agora, punida com detenção de três meses a um ano, e multa, a conduta incriminada apresenta uma forma qualificada, punida com pena de seis meses a um ano de detenção, além da multa, se o ato for realizado em monumento ou coisa tombada em virtude do seu valor artístico, arqueológico ou histórico.

A questão que se coloca, no entanto, e que certamente dependerá mais da construção jurisprudencial do que da interpretação doutrinária é a de se poder caracterizar em certos casos a simples manifestação de formas artísticas de expressão através do método da pichação ou da grafitagem que em tese devem produzir o efeito contrário ao da chamada poluição visual, embelezando ao invés de enfeiar os logradouros e edificações da cidade.

Tal é a conclusão a que se chega pela redação dada ao dispositivo citado, em que os termos "pichar" e "grafitar" são tomados no sentido pejorativo e depreciativo, como formas de "conspurcar" que não se esgotam nessas duas modalidades. Essa é, na verdade, a ofensa ao senso estético resultante da degradação do meio ambiente urbano ou da paisagem notável que se procura impedir como um dos objetivos da sua tipificação penal.

Apesar da pouca importância concedida no Brasil a essa forma de poluição, a sua criminalização vem atender às exigências da reprovação social dos atos de vandalismo praticados contra o ordenamento urbano e a configuração de seus bens constitutivos, os quais nem sempre são suscetíveis de avaliação econômica de molde a configurar um dano patrimonial ajustável às espécies de delitos já previstos na legislação penal precedente.

São Paulo, agosto de 1998. 